\title{
Early Stage of Observation of Open Distance Learning Concept for Introduction to C Programming Course in Malaysia
}

\section{Arni Munira Markom, Yusrina Yusof and Shahidah Sadimin}

To Link this Article: http://dx.doi.org/10.6007/IJARBSS/v11-i10/11045

DOI:10.6007/IJARBSS/v11-i10/11045

Received: 02 August 2021, Revised: 27 August 2021, Accepted: 20 September 2021

Published Online: 04 October 2021

In-Text Citation: (Markom et al., 2021)

To Cite this Article: Markom, A. M., Yusof, Y., \& Sadimin, S. (2021). Early Stage of Observation of Open Distance Learning Concept for Introduction to C Programming Course in Malaysia. International Journal of Academic Research in Business and Social Sciences, 11(10), 134-143.

Copyright: (c) 2021 The Author(s)

Published by Human Resource Management Academic Research Society (www.hrmars.com) This article is published under the Creative Commons Attribution (CC BY 4.0) license. Anyone may reproduce, distribute, translate and create derivative works of this article (for both commercial and non-commercial purposes), subject to full attribution to the original publication and authors. The full terms of this license may be seen at: http://creativecommons.org/licences/by/4.0/legalcode

Vol. 11, No. 10, 2021, Pg. 134 - 143

Full Terms \& Conditions of access and use can be found at http://hrmars.com/index.php/pages/detail/publication-ethics 


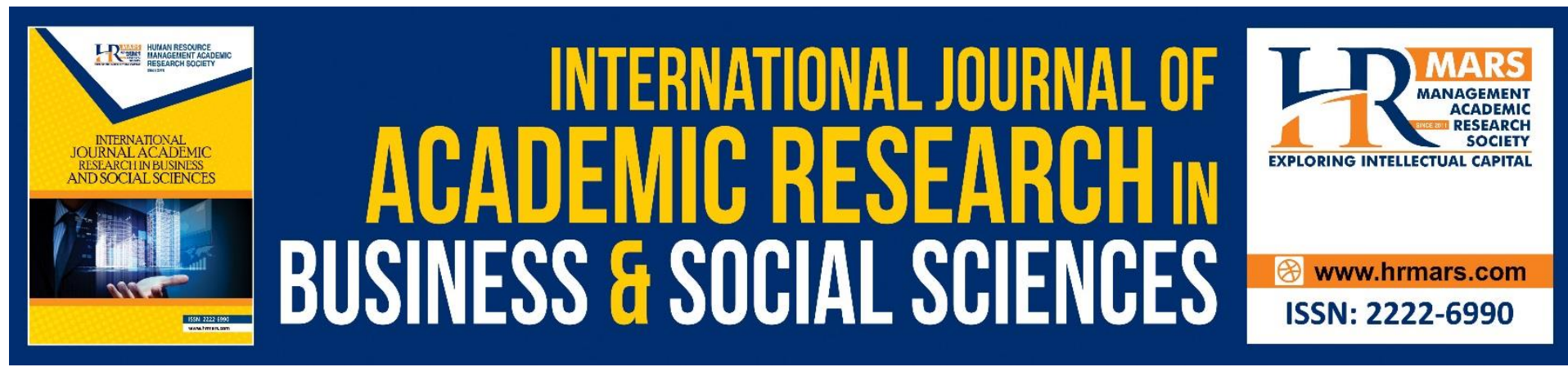

\title{
Early Stage of Observation of Open Distance Learning Concept for Introduction to C Programming Course in Malaysia
}

\author{
Arni Munira Markom ${ }^{1}$, Yusrina Yusof ${ }^{2}$ and Shahidah Sadimin ${ }^{1}$ \\ ${ }^{1}$ School of Electrical Engineering, College of Engineering, Universiti Teknologi MARA, 81750 \\ Masai, Johor, Malaysia, ${ }^{2}$ School of Electrical Engineering, College of Engineering, Universiti \\ Teknologi MARA, 40450 Shah Alam, Selangor. \\ Email: arnimunira@uitm.edu.my, yusrin262@uitm.edu.my
}

\begin{abstract}
Open Distance Learning (ODL) concepts have been a priority since 2020 due to the Covid-19 pandemic, including in Malaysian educational teaching and learning. The main benefit of this approach is the flexibility of the students in terms of distance who can learn and access from anywhere. However, limited internet data connectivity and facilities had prevented some students from joining the new educational standards of ODL. The introduction to the $C$ programming course was also affected by this new norm of education. Plus, this course is one of the toughest courses even when it comes to face-to-face learning concepts. In fact, learning $C$ programming is essential to improving the automated ability to recognize, measure, collect, manipulate, analyze, and interpret data and information. From the first day of the course, an ODL teaching strategy was planned, organized, and implemented, using the previous successful concept of lectures, laboratory exercises, and blended learning. Hence, the aim of this paper is to observe the early reaction of students to the ODL approach to teaching and learning an introduction to $\mathrm{C}$ programming courses. This paper was carried out in a survey design method with the correspondents of 86 diploma students from the Faculty of Electrical Engineering, Universiti Teknologi MARA, Cawangan Johor, Kampus Pasir Gudang. The findings show that the majority of students were able to use and be satisfied with the ODL approaches, particularly with the help of Code Block's software, in order to improve their understanding and programming skills for this course. Students were also able to organize their learning style and develop strategies such as reviewing the recorded lecture, asking the instructor, finding other open-source materials, studying in a group, and doing additional exercises. In summary, the ODL approach requires two-way communication and effort from both students and faculty in order to achieve the learning outcomes of this course. For future research, we will examine student response at the end of the semester and relate it to their result-oriented performance.
\end{abstract}

Keywords: Open Distance Learning, Online Learning, Blended Learning, C Programming Course, Code Block Software. 


\section{Introduction}

One of the crucial courses especially for electrical engineering students in computer programming either in $\mathrm{C}$ or $\mathrm{C}++$ languages. $\mathrm{C} / \mathrm{C}++$ programming is a computer-based and compulsory course for most electrical engineers, either at graduate or undergraduate level, worldwide. Dennis Ritchie was the founder of the Clanguage in 1972 when he designed the UNIX operating system at Bell Laboratories (Deitel and Deitel, 1992). Therefore, as a lecturer, it is important to emphasize the importance and usefulness of this course for the future work and development of the students. Because this topic is a key for the future industrial revolution 5.0 (I.R. 5.0) to build a smart city with everything that can be controlled anywhere via a handphone or laptop anywhere (Colombo et al., 2017; Ismagiloiva et al., 2019).

In the world of digitalization, $\mathrm{C}$ programming opens up more opportunities for their future job as listed by Anthony Grant (2017) such as programmer, software engineer, computer engineer, database developer, mobile developer, data scientist, and various startups companies with programming-based projects. $\mathrm{C}$ programming is also a foundation for artificial intelligence (Al) technology (Dimiduk, 2018). It thus offers the opportunity to create jobs for machine learning and deep learning engineers. The course remains current and important, also for the next few decades.

The Covid-19 pandemic triggered a chaotic situation in early 2020 and had an impact on the education system worldwide (Onyema et al., 2020). Due to the strict requirements of the Standard Operating Instructions (SOP) of our government of Malaysia for the protection of the population, universities must adhere to the Open and Distance Learning (ODL) approach (Jegathesan et al., 2018). Ozgur and Kocak (2016) said that the ODL philosophy aims to break down barriers and take a learner-centered approach by offering open and flexible time that suits students' needs. Nevertheless, the educational gap and other challenges due to poverty, cultural problems and infrastructural disadvantages, in particular limited internet connection and a lack of technical equipment, have widened (Gulati, 2008).

In Malaysia, ODL has had a rather surprising impact on faculty and students, from traditional face-to-face teaching and learning in a lecture class or laboratory to facing a new norm based on a full online classroom. Nevertheless, the ODL is also seen as the most efficient and effective approach to solving education and training during pandemics. Joschka (2021) shows a statistical internet access rate from 2010 to 2025 in Malaysia. It shows that $88.56 \%$ of the Malaysian population used the internet and it is expected to increase by $89.6 \%$ by the end of 2025 . About $11 \%$ usually stayed in rural areas, particularly Sabah and Sarawak. Some universities, including Universiti Teknologi MARA, are taking an initiative to allow students with limited internet and limited facilities to stay and stay on campus for a better education provider.

In an early phase of ODL, which was to be implemented in this course Introduction to $C$ programming at our university, we tried to keep the successful traditional approach of teaching strategies and to transfer it to this ODL approach. So, in this paper we conducted a survey to get the ODL feedback from students on this new concept of the learning process. The aim of this study is to observe students' early response to the ODL approach and their preparation for achieving the learning outcomes of this course. The analysis and discussion were also illustrated and elaborated.

\section{Learning Outcomes of the Course Design}

The learning outcomes of this course were that the students should be able to write $\mathrm{C}$ programming based on technical applications, design a program with a code block software, 
and demonstrate oral and written skills in the computer programming course in a group project as a mini project. Code block software is considered an excellent choice to achieve these learning outcomes as well as to improve students' programming skills because it is free, open source, easy to install, and easy to use.

\section{Organization of the Course Contents}

There are six course outline contents as shown in Figure 1. It starts with the initial concepts of $\mathrm{C}$ programming, followed by decision statements for if, if else, and if else if. Then the course continues with repeated loop statements for finite and infinite program repetition. Then a functions, arrays and pointers.

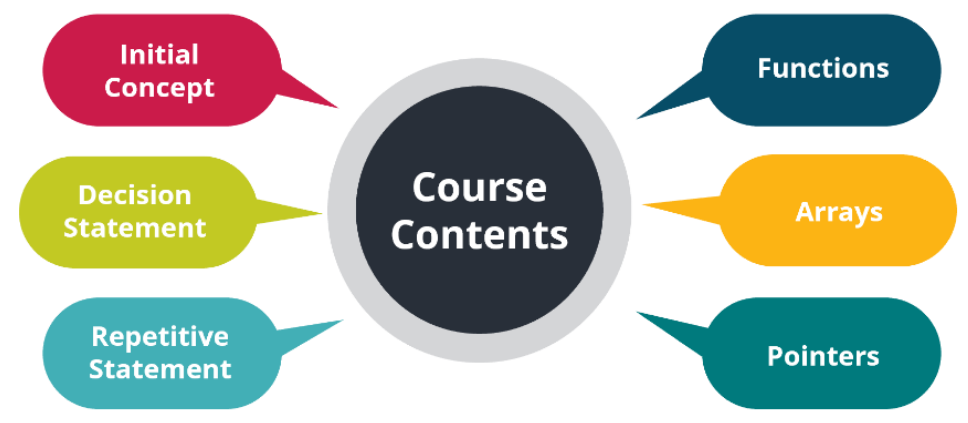

Figure 1: Course contents for an introduction to C programming.

\section{ODL Teaching Strategies}

Typically, for a traditional face-to-face approach, there are three teaching strategies as illustrated in Figure 2: lectures, lab exercises, and blended learning. So far, for many years, these three strategies have been effective ways to get better results-oriented learning and positive feedback from students.

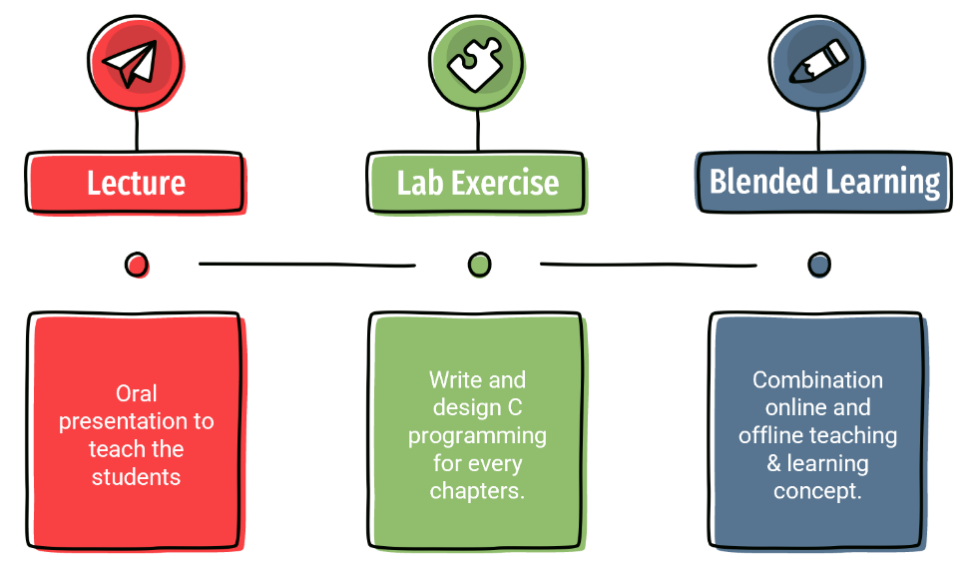

Figure 2: ODL Teaching Strategies

The concept of teaching strategies was retained in the ODL approach. The lecture was carried out like a normal lecture via an online platform. Laboratory exercises are given after completing each chapter in the same week. However, only part of the blended learning can be used in ODL. This is because blended learning has to combine both the face-to-face and online learning approaches. Nevertheless, the online part of blended learning has been renewed with various online tools such as Google Meet, Google Classroom, Microsoft Team, E-Mail and WhatsApp. 
WhatsApp is the easiest and fastest way to communicate with students in a group or in person. In an early stage of ODL, email was used for submitting lab reports and assignments, while Google Meet was used for lectures. However, these tools have been changed to a better platform with the help of Microsoft Team. Microsoft team then became the main tool for our teaching and learning. This tool provides online streaming of online lectures, core lesson plans and materials, and any reports and assignments submitted by a group or individuals. Participation can also be easily downloaded from this platform. Google Classroom is an effective tool for sharing instructor grading for student tests or homework.

Basically, this course consists of 6 laboratory exercises for 6 chapters. The concept of learning to code is the same concept when we are practicing learning math. Practice and keep practicing creating a program. Open source, free, and easy-to-install code block software was introduced to help students practice programming anywhere. In the first week, all students were taught to install and write simple code to become familiar with the software.

\section{Methodology}

\section{A. Sample}

A sample of 86 students in the second semester of diploma in electrical engineering in the Faculty of Electrical Engineering, Universiti Teknologi MARA, Cawangan Johor, Kampus Pasir Gudang was selected for the academic calendar from October 2020 to February 2021. There were 48 students majoring in electronics while the remaining of 38 students was majoring in power. The topic was Introduction to C programming with the code of ECE 128. The sample was taken from a survey with the Google Form Tool and the title of the survey was ECE 128 Student Open Distance Learning Feedback Form.

\section{B. Instruments}

For this observation, a survey instrument was used to examine the teaching approach of the lecturers and the ODL feedback on this topic of the ECE 128. 1 disagree, while 4 totally agree. In the meantime, the second tool has been used to measure student satisfaction with the ODL class, using the ordinal scale of 5 and the nominal scale for yes and no questions.

\section{Research Procedures}

The students were introduced to ODL teaching plans, materials and platforms for this course with the three strategies of lectures, laboratory exercises and blended learning. Then, they were assigned to download and use an open source for $\mathrm{C}$ programming code called Code Block. After 5 weeks of assigning induction and some laboratory assessments, this survey was conducted to measure their perceived motivation towards the $\mathrm{C}$ programming course using code block based on the ODL class.

\section{Analysis and Results}

For the teaching approach of the lecturers, it was considered with Figure 3 for the students how well their lecturer demonstrates in-depth knowledge of the respective course of study. 41 students strongly agree that the lecturer shows profound knowledge of the course, 44 students agree and 2 students disagree with the lecturer's ability. Figure 4 is intended to determine the thoughts of the students with their lecturer appearance in relation to enthusiasm and interest in the ODL class. 85 students agreed that their lecturer had fun and passion for teaching ODL. 


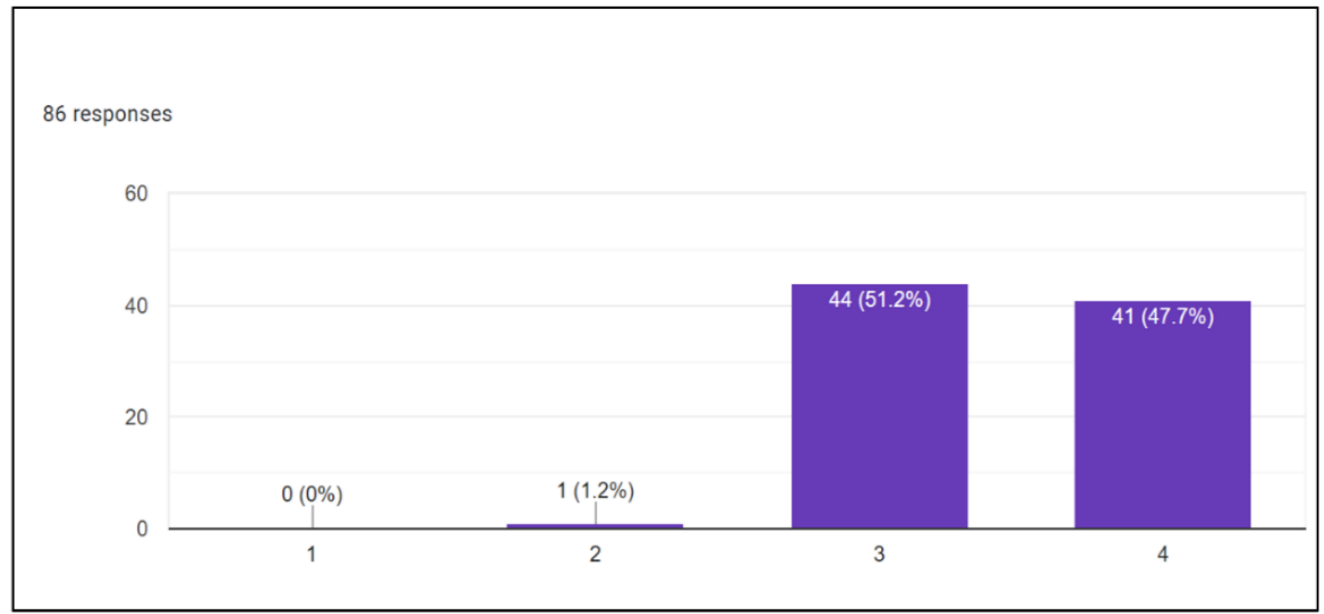

Figure 3: Lecturer demonstrates in-depth knowledge of this course.

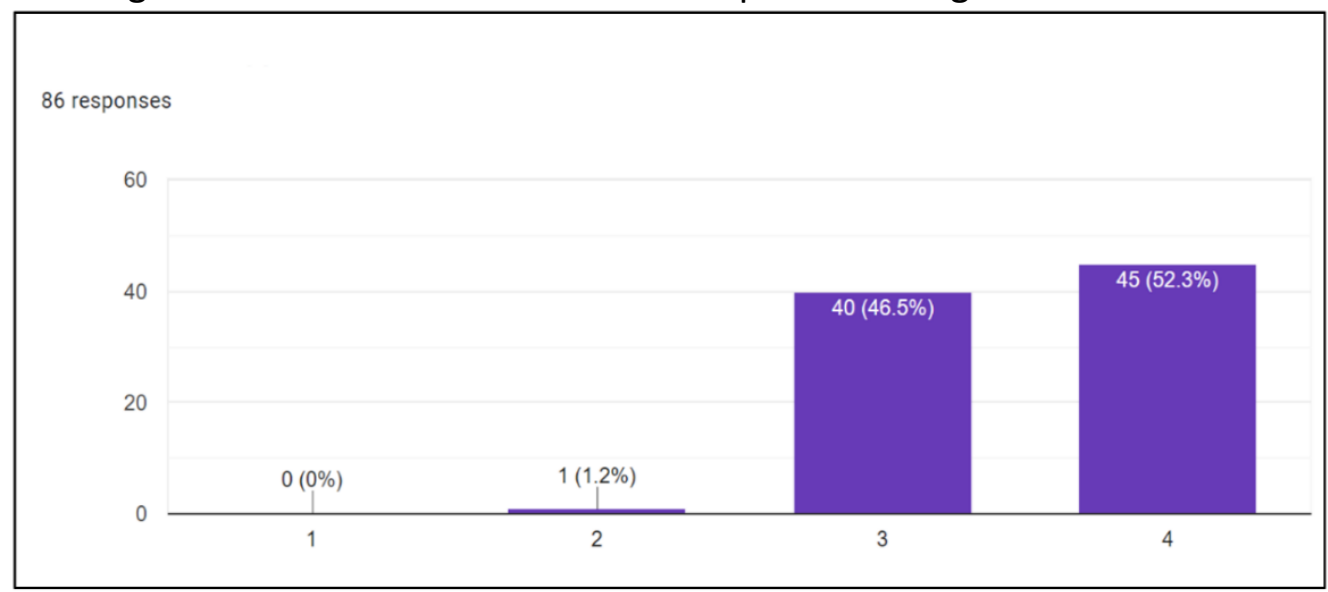

Figure 4: Lecturers show an enthusiastic and interesting attitude.

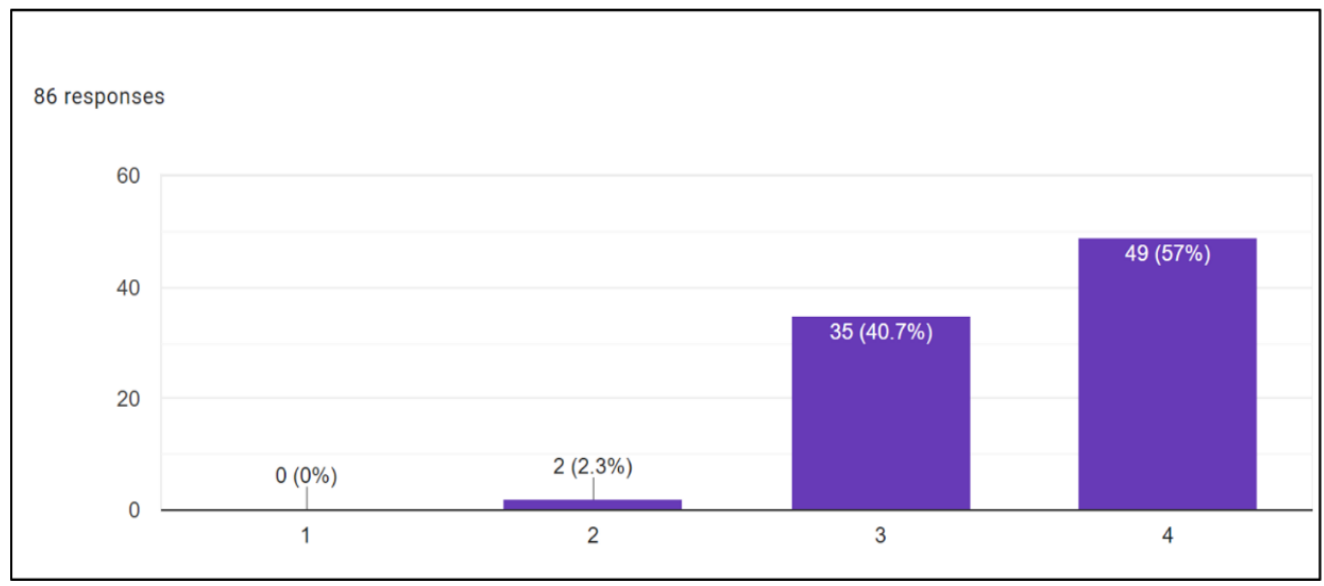

Figure 5: Lecturer explains concept clearly. 


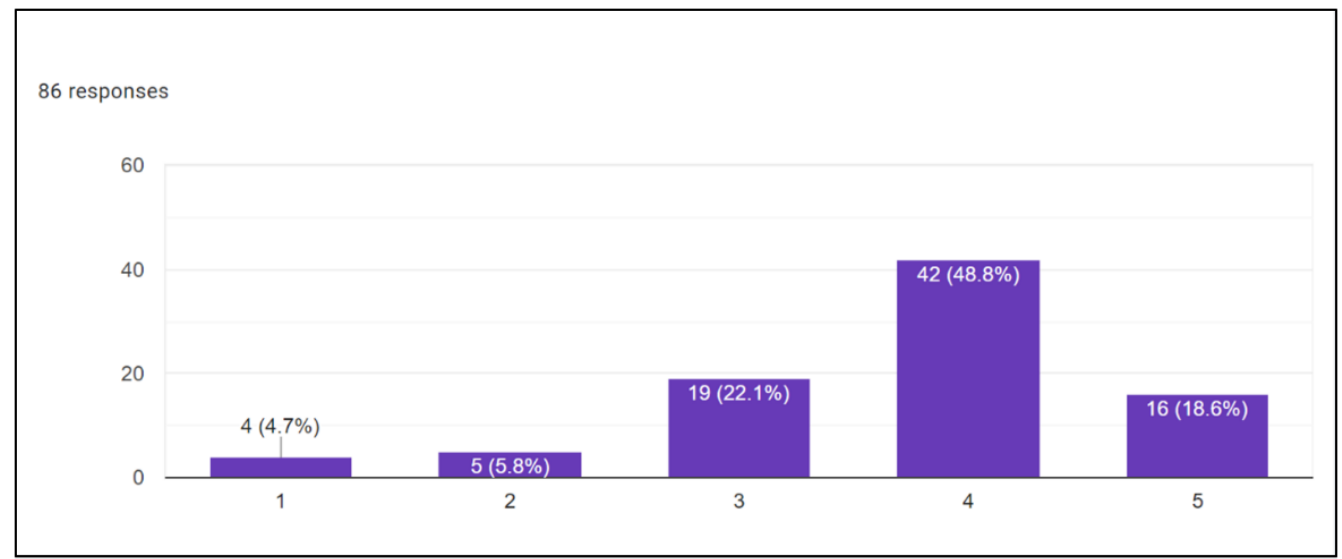

Figure 6: The positive feeling of the students after studying the introduction to $C$ programming according to the ODL approach.

The lecturer clearly explained the programming concept in question 3 , as shown in Figure 5. 49 students were understood very well, 35 students were understood and only 2 students fail to understand the concept of teaching and learning of the course based on ODL class. Then, Figure 6 is a question for Instrument No. 2 for the ODL feedback on the ECE 128 course. $67.4 \%$ of the students strongly agreed and agreed to measure their positive feeling about learning this course on the online platform. $22.1 \%$ were neutral and $10.5 \%$ of the students did not agree to experience this course during the ODL.

Figure 7 shows a pie chart of the ease of accessing the code block's open source software. 85 students or $98.8 \%$ of the students stated that the software was easy to get on the website. To measure the usefulness of the code block software for this course, it has been described in Figure 8. 96.5\% agreed that this software would be useful in understanding this course. Only 3 students disagreed with the usefulness of this software. The students were then asked about the importance of this course for their degree in electrical engineering with a focus on power or electronics as illustrated in Figure $9.78 .7 \%$ of the students agreed with the importance of this course, $15.1 \%$ of the students were neutral and $1.2 \%$ of the students or only one person disagreed with this statement.

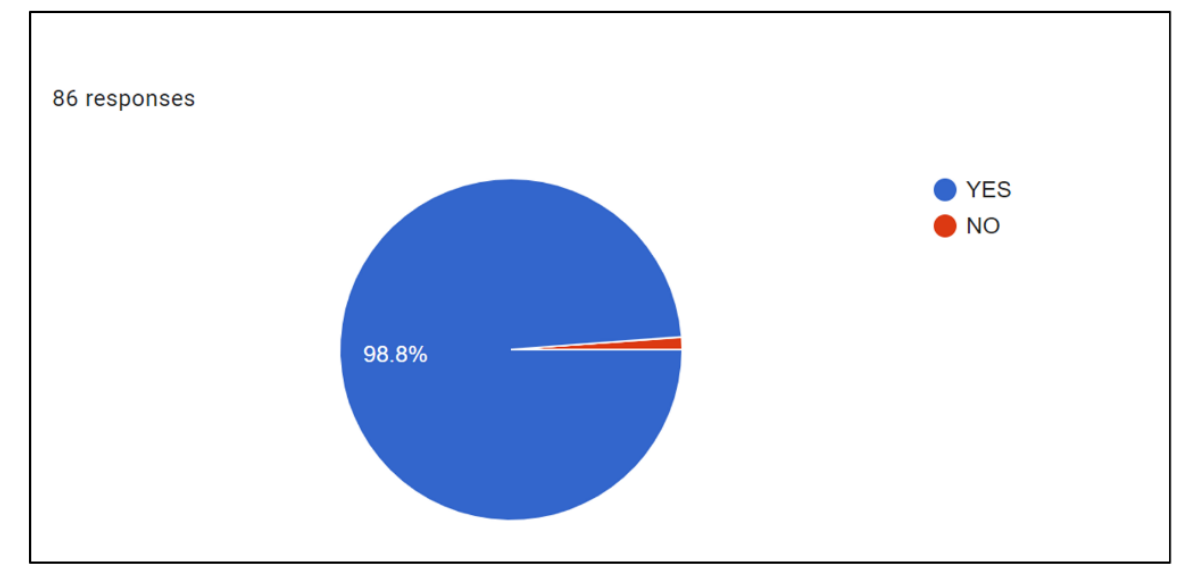

Figure 7: Student feedback on easy access to the code block software. 


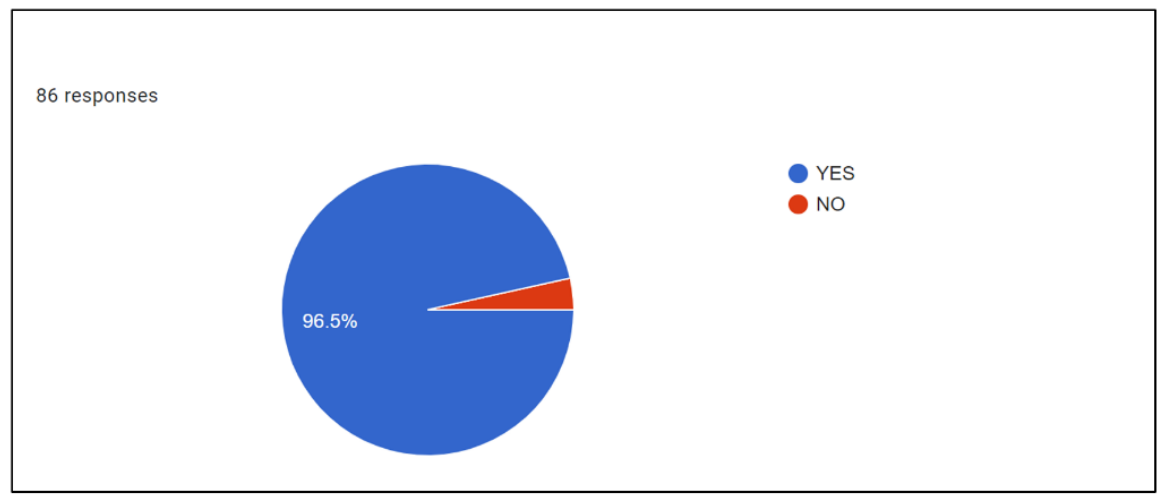

Figure 8: The usefulness of the code block software in understanding this course.

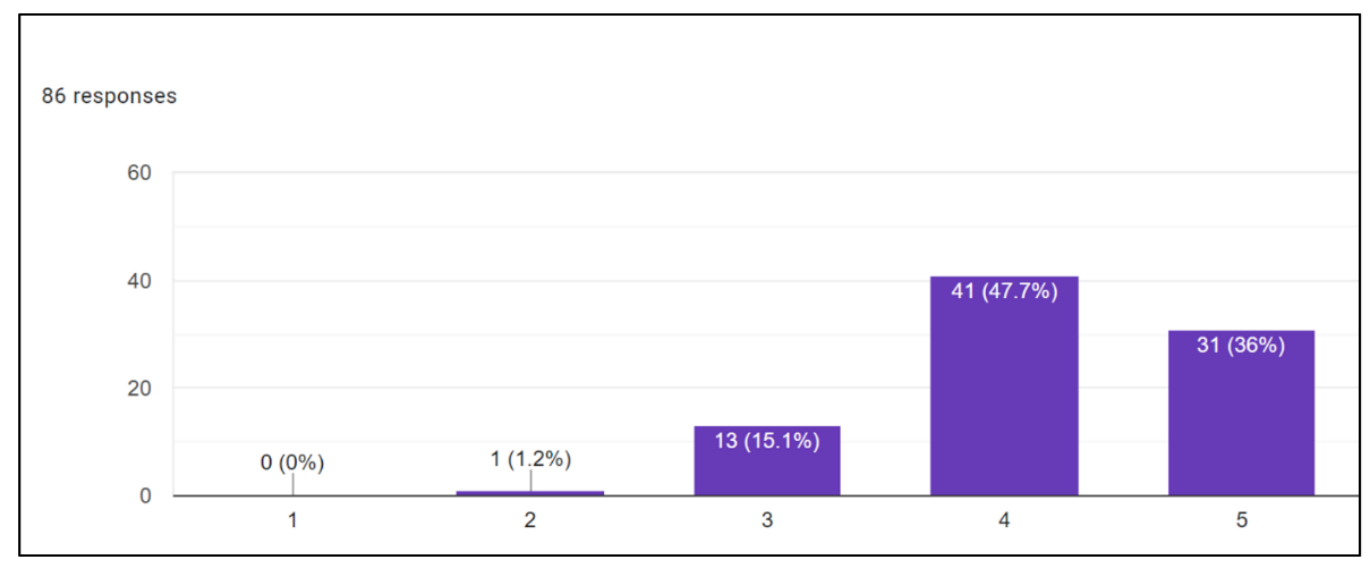

Figure 9: The importance of this course from the perspective of the students.

Finally, a subjective question for the students. How do you organize yourself to improve this course? and the data are shown in Table 1 . The least activity for 4 students was repeating the recorded lecture to improve their course performance. Then 7 students ask the lecturer if they don't understand him after class. Interestingly, 8 students show an alternate path by finding another source to improve their understanding such as in YouTube and Google. 13 students conveniently developed a group study or asked their friends to solve a program given in class. Overall, all students improve self-study and do additional exercises with the code block software in order to improve the course results of the introduction to $C$ programming.

Table 1: Students organization and strategies to improve on Introduction to C Programming.

\begin{tabular}{|c|l|c|}
\hline No & \multicolumn{1}{|c|}{ Activity } & $\begin{array}{c}\text { No. of } \\
\text { students }\end{array}$ \\
\hline $\mathbf{1}$ & Re-play the recording lecture & $\mathbf{4}$ \\
\hline $\mathbf{2}$ & Ask lecturer if not understand & $\mathbf{7}$ \\
\hline $\mathbf{3}$ & $\begin{array}{l}\text { Find another sources example in YouTube and } \\
\text { Google }\end{array}$ & $\mathbf{8}$ \\
\hline $\mathbf{4}$ & Study group or asking friend & $\mathbf{1 3}$ \\
\hline $\mathbf{5}$ & Self-study and do extra exercises & $\mathbf{8 6}$ \\
\hline
\end{tabular}

\section{Discussion}

The sudden change from the traditional approach to the ODL approach increased the fear among students and lecturers. Thus, the first instrument aimed to determine their 
confidence and motivation when a reliable and competent lecturer conducted the course via an online platform. The students were observed the behavior of the lecturers in order to plan, prepare and demonstrate this course. It turns out that the majority of the students felt that their instructor was very knowledgeable and showed an excellent demeanor of enthusiasm and interest to teach this course. In addition, the lecturer succeeded in clearly explaining the concept of the course.

Only 1 to 2 students disagreed with the behavior of the lecturers and with the wellunderstood concept of the course. This is because at an early stage of the ODL class these students had limited internet connection and a lack of computers. After recognizing this problem, the lecturer demonstrated another method using a $\mathrm{C}$ programming application in smartphones to continue her learning process. In addition, some students with these problems were allowed to return to campus for internet and facilities by university.

More than half of the students are still looking forward to learning this course through the ODL process with a positive feeling. However, others were neutral in the middle and some of the students didn't like ODL to study programming. The students began to understand the new norm of the teaching and learning concept that we could not avoid due to the current pandemic situation.

Still, the majority were satisfied with the code block software because it is free, open source, easy to install, and very useful for creating a program in the $C$ language. The lecturer can perform and write a program during the online class, followed by the students for each chapter. Therefore, communications can still be conducted in two ways, as traditional methods of learning and understanding this programmable course.

72 students agreed that this course is important for their future work. This is because lecturers make the importance of this degree clear in their graduation project at the end of the semester and will repeat the same course if they want to continue their studies at the bachelor's degree level. In addition, the lecturers emphasized their future professional advantages of this programming language.

Finally, all 86 students were asked a subjective question about how they organize their studies to improve their performance in this Introduction to C Programming course. Repeating the lecture recording was the least attractive to the students. Although this video recording is seen as a benefit in ODL, the students cannot take advantage of this benefit. The advantages of recording are that students who need more processing time can pause and rewind the video can benefit from the repetition, watch it as many times as they want, take notes at their own pace, and benefit from taking notes to review a transcript.

Some students will ask the instructor if they don't understand their exercise or need to solve bugs in their program. This is because most students tend to ask around the class or wait for the next class to ask about their bugs. Some of the students have a preferred approach by finding another source like YouTube and the Google platform, developing a group study, and asking their friends as another good strategy to solve and improve their studies. The best part was that all students self-paced to practice the code block software and improve their knowledge, understanding, and skills in executing and creating $C$ programming code.

\section{Conclusion}

To sum up, this ODL requires two-way communication and effort for both students and lecturer in order to achieve the learning outcomes for this course of introduction to $C$ programming. While the lecturers are doing their best to plan, organize, and deliver the 
lectures, the students also tried to improve their understanding and skills, including practicing $C$ programming writing. Students manage to integrate the ODL approach and improve their performance with teaching and learning strategies from online lectures such as regular faceto-face sessions, lab exercises to improve their skills, and a mini report to monitor their overall performance by solving an engineering problem in a group. In addition, they are performing excellently as they understand the importance of this degree for their future careers.

\section{Acknowledgment}

This work is supported by Ministry of Education (MoE) Malaysia under grant 600IRMI/FRGS RACER 5/3 (107/2019).

\section{Reference}

Anthony Grant. (2017). 10 Computer Programming Careers and Jobs That Are in High Demand. Retrieved 8 May 2017 from make use of online technology publications: https://www.makeuseof.com/tag/computer-programming-jobs-in-demand/

Colombo, A. W., Karnouskos, S., Kaynak, O., Shi, Y., \& Yin, S. (2017). Industrial cyberphysical systems: A backbone of the fourth industrial revolution. IEEE Industrial Electronics Magazine, 11(1), 6-16.

Deitel, H. M., \& Deitel, P. J. (1992). C: how to program. Prentice-Hall, Inc.

Dimiduk, D. M., Holm, E. A., \& Niezgoda, S. R. (2018). Perspectives on the impact of machine learning, deep learning, and artificial intelligence on materials, processes, and structures engineering. Integrating Materials and Manufacturing Innovation, 7(3), 157172.

Ismagiloiva, E., Hughes, L., Rana, N., \& Dwivedi, Y. (2019, June). Role of smart cities in creating sustainable cities and communities: a systematic literature review. In International Working Conference on Transfer and Diffusion of IT (pp. 311-324). Springer, Cham.

Jegathesan, R., Noryati, A., Hisham, A. J., \& Nordiana, W. H. (2018). Learners' Satisfaction and Academic Performance in Open and Distance Learning (ODL) Universities in Malaysia. Global Business and Management Research: An International Journal, 10(3).

Müller, J. (2021). Internet user penetration Malaysia 2010-2025. Retrieved 11 August 2021 from statisca.com: https://www.statista.com/statistics/975058/internet-penetrationrate-in-malaysia/

Kose, U., \& Deperlioglu, O. (2012). Intelligent learning environments within blended learning for ensuring effective $C$ programming course. arXiv preprint arXiv:1205.2670.

Onyema, E. M., Eucheria, N. C., Obafemi, F. A., Sen, S., Atonye, F. G., Sharma, A., \& Alsayed, A. O. (2020). Impact of Coronavirus pandemic on education. Journal of Education and Practice, 11(13), 108-121.

Özgür, A. Z., \& Koçak, N. G. (2016). Global tendencies in open and distance learning. Journal of Education and Human Development, 5(4), 202-210. 